\title{
Decision Making within the Built Environment as a Strategy for Mitigating the Risk of Malaria and Other Vector-Borne Diseases
}

\author{
Esther Obonyo $^{1, * \mathbb{C}}$, Sumit Pareek ${ }^{2}$ and Dawit Okubatsion Woldu ${ }^{3}$ (B) \\ 1 School of Engineering Design and Architectural Engineering, College of Engineering, Pennsylvania State \\ University, University Park, PA 16802, USA \\ 2 Department of Chemical Engineering, College of Engineering, Pennsylvania State University, \\ University Park, PA 16802, USA; sqp5489@psu.edu \\ 3 Anthropology and Cross-cultural Studies Program, College of Human Sciences and Humanities, \\ University of Houston Clear Lake, Houston, TX 77573, USA; woldu@uhcl.edu \\ * Correspondence: eao4@psu.edu; Tel.: +814-865-2952
}

Received: 2 November 2018; Accepted: 7 December 2018; Published: 21 December 2018

\begin{abstract}
Although significant efforts have been made to combat the spread of vector-borne diseases (VBDs), they still account for more than $17 \%$ of all infectious diseases. According to the World Health Organization (WHO), there were 216 million estimated cases in 2016. The efforts that resulted in these positive outcomes lack long-term financial sustainability because of the significant amount of funding involved. There is, therefore, a need for more cost-effective intervention. The authors contend that design decisions in the built environment can have a positive impact on the efforts directed at mitigating the risk of malaria in a more cost-effective manner. It is known that the built environment, through features such as openings, can propagate the spread of malaria. There have been some significant efforts directed at addressing this risk. This notwithstanding, an extensive review of closely related work established that built environment professionals have limited access to information on specific ways through which their design decisions can contribute to mitigating the risk of malaria. The validity of this hypothesis was tested through evaluating the opportunities for synergies in selected parts of East Africa. Secondary data derived from relevant urban health journals as well as repositories curated by leading health agencies such as WHO were synthesized and analyzed using a web of causation approach. The outcome of the analysis is a schema of primary and secondary source (risk) factors. The use of the web of causation approach revealed the existing factor-to-factor interactions that could have a reinforcing effect. This information was used to identify the critical linkages and interdependencies across different factors. The outcome of the analysis was mapped against risk factors that can be linked to decisions made during the six primary phases of the construction life cycle: Preliminary phase, conceptual design, detailed design, construction, facilities management, and end of life/disuse. A conceptual architecture for a decision support framework has been proposed and will be developed into a prototype in subsequent efforts.
\end{abstract}

Keywords: built environment; design decisions; vector-borne diseases; malaria risk mitigation

\section{Introduction}

The overarching goal for the research discussed in this paper is assessing the potential for mitigating the risk of vector-borne diseases (VBDs) through health-centric design criteria for the built environment. In 2016, there were an estimated 216 million cases of malaria in 91 countries (World Health Organization), [1] which surpasses the prevalence of other tropical or neglected diseases, such as HIV / AIDS and dengue fever [1-6] (see Table 1). 
Table 1. Infectious disease cases [1-6].

\begin{tabular}{cc}
\hline Tropical Disease & Number of People Infected in $\mathbf{2 0 1 6}$ \\
\hline Malaria & 216 million \\
HIV / AIDS & 36.7 million \\
Tuberculosis & 10.4 million \\
Dengue & 3.2 million \\
Leprosy & 200,000 \\
Ebola & 28,600 \\
\hline
\end{tabular}

There were approximately 445,000 VBD-related deaths in 2016 [1]. Some of the most successful interventions have been brokered by the World Health Organization (WHO) Global Malaria Program through partnerships with government and regulatory authorities in endemic countries [7]. Such efforts have resulted in positive outcomes, such as a $9.3 \%$ decrease in the number of reported cases of malaria between 2006 and 2016 [8]. Although the number of reported malaria cases may have decreased in some developed nations, malaria is still severe in developing and emerging economies, as shown in Figure 1. Regions closer to the equator had higher prevalence, and regions farther away were either formerly malarious or never malarious [9]. The larger number of deaths from malaria was concentrated in sub-Saharan Africa (see Figure 2). Consequently, international agencies such as the USAID, WHO, Wellcome Trust, Roll Back Malaria Group, and the Presidential Malaria Initiative (PMI) continue to invest millions of dollars in malaria-related intervention programs in Sub-Saharan Africa (SSA).

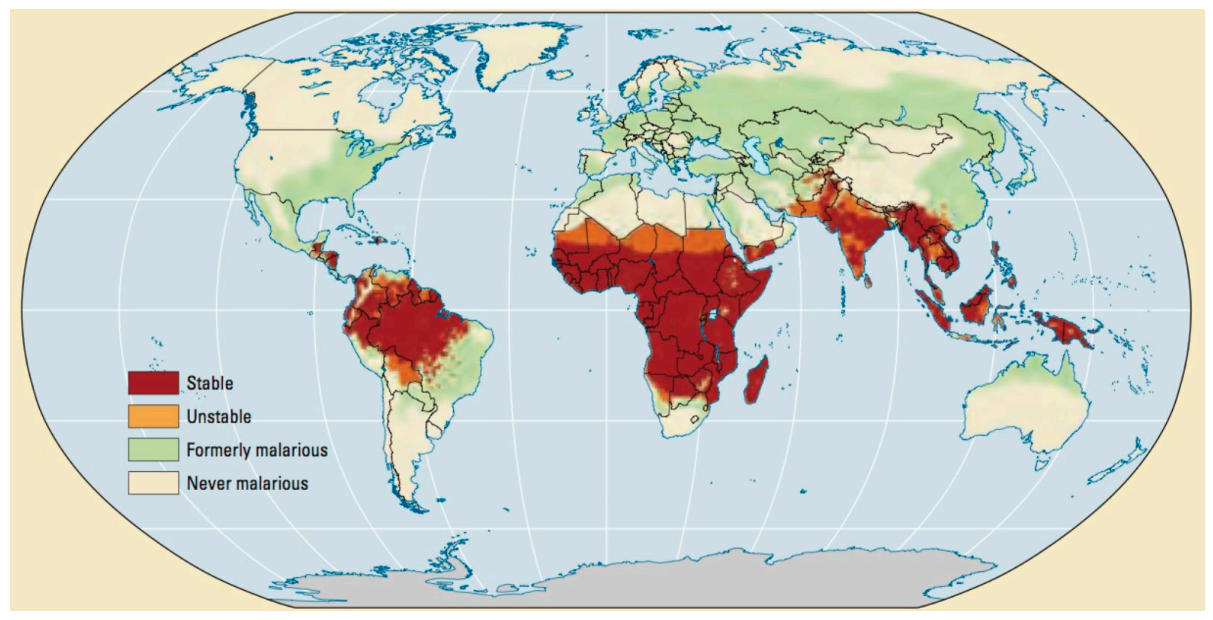

Figure 1. Severity of malaria prevalence in 2009 [9].

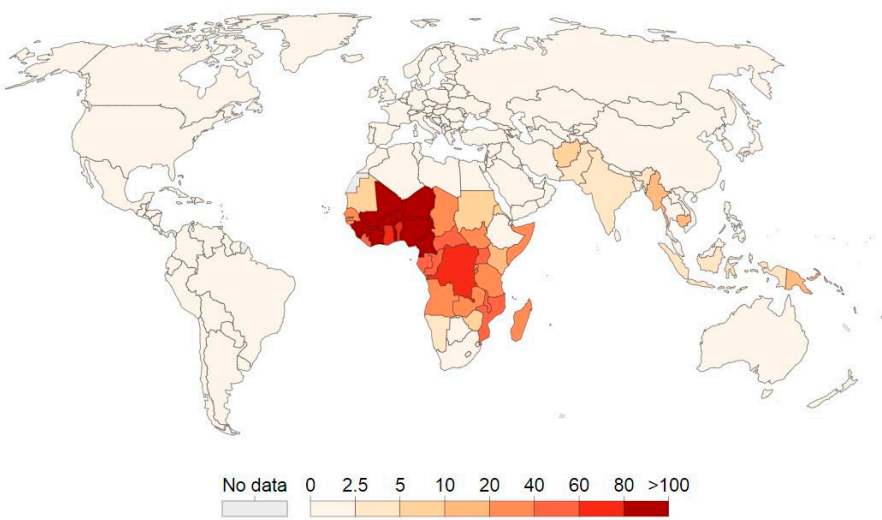

Figure 2. Malaria death rates per 100,000 [9]. 
The efforts that resulted in the reported positive outcomes lack long-term financial sustainability because of the significant amount of funding involved. This is exemplified by the Global Fund's budget for malaria prevention-over USD 9.1 billion was disbursed in 2016, which represents a 90\% increase in funding levels from the previous decade [10]. There is an opposing trend of decreasing estimated cases of malaria per year and increasing costs for malaria prevention has been depicted in Figure 3 [10-12]. In addition to the financial burden, progress towards the elimination of malaria is further impeded by quality-related concerns over drug efficacy, safety, and surveillance [7]. Clearly, the current approach to managing the risk of VBDs such as malaria will not deliver the kind of transformative impact that is required to accelerate progress towards the elimination of the disease.

The authors propose to address this need through an agenda for malaria-proof buildings that is more closely aligned with the United Nations Sustainable Development Goals (UN SDGs), specifically SDG \#11: "Make cities and human settlements inclusive, safe, resilient, and sustainable" [13,14]. The proposed approach predicates on the high-level targets set by the New Urban Agenda (NUA), a global, nonbinding agenda adopted during the October 2016 Habitat III convening in Quito, Ecuador [15]. It escalates the need for more convergence between health and the built environment sectors. It recognizes that the shape and form of urban development influences the health of city residents. The professionals who design, plan, build, and govern cities exercise great influence over the basic ingredients of a healthy life, including access to decent housing, clean air and water, nutritious food, safe transport and mobility, opportunities for physical activity, and protection from injurious risks and toxic pollutants. An urban space that offers these fundamental, health-enabling conditions can dramatically reduce the incidence of and costs associated with a wide range of diseases, including VBDs such as malaria. In the subsequent section, the authors review closely related work focusing specifically on efforts that address built environment-related factors that have a bearing on malaria. This is followed by a description of the methodology adopted for the research and a deep analysis of the key findings from the research. The paper concludes with a description of areas for further research.
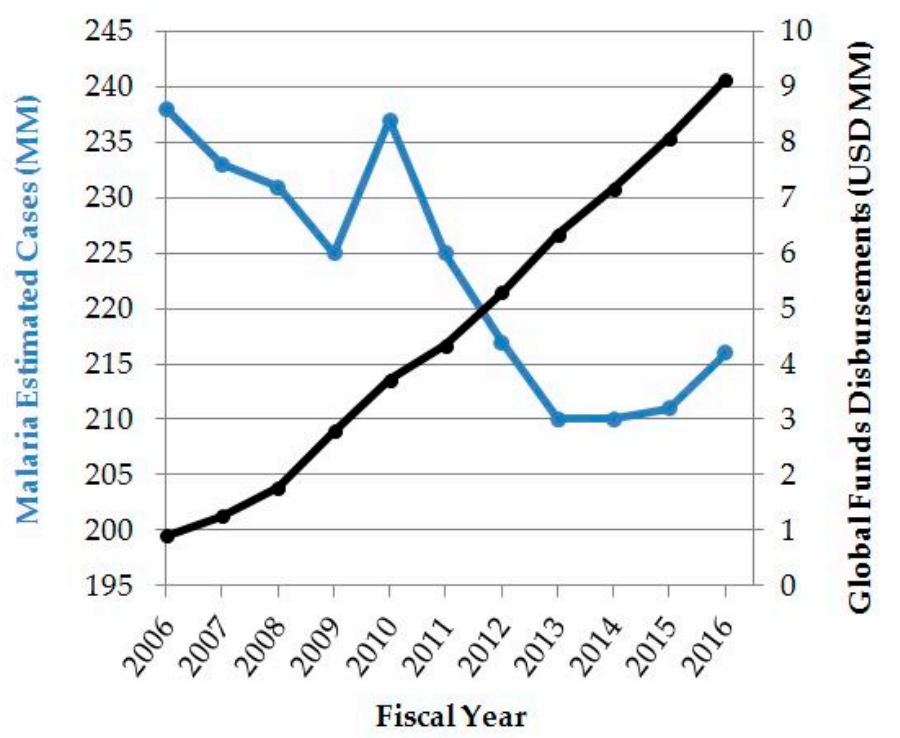

Figure 3. Relationship between global spending trends and estimated cases of malaria [10-12].

\section{Review of Closely Related Work}

It is known that an effective design and construction of buildings and other assets can help to combat the spread of vector-borne diseases [16-19]. This is evident from the malaria intervention program implemented during the construction of the Panama Canal. According to the Centers for Disease Control and Prevention (CDC), built environment-related strategies, such as pool drainage 
near homes, bush cutting, and building screening, resulted in a decrease in the percentage of malaria-induced hospitalizations of the workforce from 9.6 to $1.6 \%$ between 1905 and 1909 [20].

There are several interventions that have leveraged lessons learned from the Panama Canal project. Examples include the modification of building envelopes through minimizing the size and/or number of openings, such as windows [21]. Such modifications reduce the ease with which mosquitoes gain access to a building. Other efforts focus on material selection, given the fact there is a positive correlation between the use of traditional building materials and techniques, and the prevalence of malaria [16]. There is also evidence of a relationship between the management of existing drainage systems and larval control [22], in which poor drainage can provide ideal conditions for breeding the malaria-causing mosquito. Table 2 depicts the authors' analysis of closely related work. [16-19,21-54].

Although these types of building-related intervention programs have resulted in some positive effects with respect to malaria prevention, such programs have had limited input from built environment professionals. A comprehensive review of published literature did not reveal any evidence of built environment professionals responsible for critical decision making in existing malaria intervention efforts (see examples in Table 2). In contemporary intervention programs, the overlap between the public health champions of housing modification for the control of malaria and the built environment stops at the level of construction trades. The research discussed in the subsequent sections of this paper investigates the transformative potential of early stage decision making by built environment professionals.

Table 2. Analysis of closely related work.

\begin{tabular}{|c|c|c|}
\hline \multirow[b]{2}{*}{ Motivation } & \multicolumn{2}{|c|}{ Research Focus } \\
\hline & Outcomes Assessment and Impact Evaluation & Spatial Analysis of the Spread of Malaria \\
\hline $\begin{array}{l}\text { Promoting public health from a } \\
\text { global perspective }\end{array}$ & $\begin{array}{c}\text { Mitsakakis et al., 2018; Mgone, 2010; } \\
\text { Marshall et al., 2010; Atkinson, 2011; Wang et al., } \\
\text { 2006; Marshall and De Silva, 2012; Qi, 2012; } \\
\text { Tizifa, et al., } 2018\end{array}$ & $\begin{array}{c}\text { Vajda and Webb, 2017; Hausmann-Muela } \\
\text { and Eckl, 2015; Ocampo et al., 2013; } \\
\text { Tatem, } 2014\end{array}$ \\
\hline $\begin{array}{l}\text { The link between climate change } \\
\text { and the occurrence of malaria }\end{array}$ & $\begin{array}{l}\text { Semenza, 2015; Ninphanomchai et al., 2014; } \\
\text { Reiter, 2008; Klinkenberg et al., 2008; } \\
\text { Hay et al., 2002; Adefemi et al., 2015. }\end{array}$ & $\begin{array}{l}\text { Negev et al., 2015; Zhou et al., 2007; } \\
\text { Lindblade, 2000; Tonnang, 2010; } \\
\text { Edlund et al., } 2012\end{array}$ \\
\hline $\begin{array}{l}\text { Opportunities for built } \\
\text { environment-related mitigation }\end{array}$ & $\begin{array}{l}\text { Walls et al., 2016; Lindsay et al., 2002; Menger et } \\
\text { al., 2014; Gamage-Mendis, 1991; Lindsay et al., } \\
\text { 2003, Harrysone et al., 2009; Tusting et al., 2015; } \\
\text { Tusting et al., 2016; Marshall and De Silva, 2012; } \\
\text { Atieli et al., 2009; Njau et al., 2009. }\end{array}$ & $\begin{array}{c}\text { Marshall and De Silva, 2012; } \\
\text { Waite, et al., 2016; Tusting et al., } 2017\end{array}$ \\
\hline
\end{tabular}

\section{Methodology}

The research was based on collecting and analyzing secondary data derived from repositories curated by the WHO, World Bank, and Global Funds, as well as publications from the WHO, the CDC, the United Nations (UN), the National Institute of Health (NIH), Rollback Malaria Group, and Presidential Malaria Initiative. The authors derived additional insights from academic publications such as The Malaria Journal, Tropical Medicine and International Health, and Environmental Health Perspectives.

During the formative stage of the research, the author conducted two semi-structured interviews with two East African-based professionals: (1) The Head of East and Southern Africa Operations and Capacity Building for Malaria Initiatives in an international organization, and a quantity surveyor who also works as a built environment professor at the JKUAT University in Juja, Kenya. The information collected was processed and synthesized in an iterative manner using three main steps: (1) Characterizing the factors contributing to either success or failure in the existing strategies; (2) identifying opportunities for education and engagement within intervention strategies; and (3) developing recommendations for concerted effort in the future (see Figure 4). Variables that result in the spread of malaria were characterized as source factors, which were determined from the literature. A total of 20 source factors were identified-see Table 3. These source factors can be 
attributed to triggers that are influenced by three disciplinary sectors: the built environment, public health, and climate change. Table 4 shows examples of how each sector may limit the mitigation of malaria.

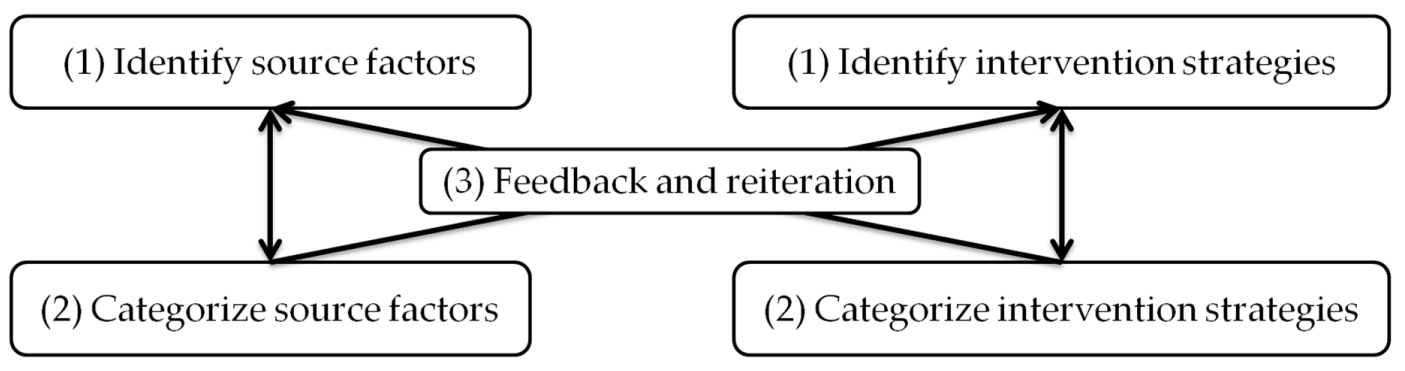

Figure 4. Three-step process model.

Table 3. List of identified source factors (Step 1).

\begin{tabular}{l}
\hline \multicolumn{1}{c}{ Malaria Source Factors } \\
\hline 1. Antibiotic resistance \\
\hline 2. Artificial breeding sites \\
\hline 3. Building envelope modifications (modifying size/placement of openings) \\
\hline 4. Changes in global wind pattern \\
\hline 5. Deforestation from land use \\
\hline 6. Desertification and drought \\
\hline 7. Higher relative humidity \\
\hline 8. Increased rainfall (precipitation) \\
\hline 9. Increased temperature \\
\hline 10. Inlets/outlets for air transfer and ventilation \\
\hline 11. Insufficient government/NGO funding \\
\hline 12. Lack of health education (e.g., hygiene practices, blood transfusion) \\
\hline 13. Low standard of living (e.g., socioeconomic status) \\
\hline 14. More excavated areas (open surface water bodies) \\
\hline 15. Urban agriculture practices \\
\hline 16. Poor housing material \\
\hline 17. Urban agriculture practices \\
\hline 18. Urbanization \\
\hline
\end{tabular}

Table 4. List of categorized source factors (Step 2).

\begin{tabular}{|c|c|c|}
\hline Built Environment & Global Health & Climate Change \\
\hline 1. Artificial Breeding Sites & 1. Antibiotic resistance & 1. Changes in global wind pattern \\
\hline $\begin{array}{l}\text { 2. Building envelope modifications } \\
\text { (modifying size/placement of openings) }\end{array}$ & $\begin{array}{l}\text { 2. Geographic residence (e.g., urban, } \\
\text { peri-urban, rural, river, coast, altitude) }\end{array}$ & 2. Deforestation from land use \\
\hline $\begin{array}{l}\text { 3. Inlets/outlets for air transfer } \\
\text { and ventilation }\end{array}$ & 3. Insufficient GOV/NGO funding & 3. Desertification and drought \\
\hline $\begin{array}{l}\text { 4. More excavated areas causing open } \\
\text { surface water bodies }\end{array}$ & $\begin{array}{l}\text { 4. Lack of health education (e.g., hygiene } \\
\text { practices, blood transfusion) }\end{array}$ & 4. Higher relative humidity \\
\hline 5. Poor housing material & $\begin{array}{l}\text { 5. Lack of synergy among } \\
\text { institutions/organizations }\end{array}$ & 5. Increased rainfall (precipitation) \\
\hline \multirow[t]{2}{*}{ 6. Urbanization } & 6. Urban agriculture practices & 6. Increased temperature \\
\hline & $\begin{array}{l}\text { 7. Low standard of living } \\
\text { (e.g., socioeconomic status) }\end{array}$ & $\begin{array}{l}\text { 7. Pollution (poor indoor } \\
\text { air quality) }\end{array}$ \\
\hline
\end{tabular}


Each intervention strategy was traced back to a source factor. A further analysis was performed to establish the nature of the relationship between each source factor and the associated intervention method where applicable, based on an assessment of relevancy. This analysis was also done to determine the extent to which the source factor in question could result in either the success or failure of the intervention strategy. The focus here was characterizing the nature of the relationship between the source factors and intervention methods in each case. For example, a growing population triggers an increased demand for Insecticide-Treated Nets (ITNs) as an intervention strategy. Increased urbanization triggers an greater need for living space, causing increased design and construction activities. The latter increases the risk of malaria infection. Urbanization therefore serves as a reinforcing factor on constraints to the use of ITNs as an intervention strategy. Relevancy assessments were performed on both the built environment intervention strategies and global health intervention strategies (see Table 5).

Table 5. Section of relevancy assessment matrix (Step 3).

\begin{tabular}{|c|c|c|c|}
\hline & & Built Environment Intervention Strategy & Global Health Intervention Strategy \\
\hline & & 1. Screened eave tubes (SET) & $\begin{array}{l}\text { 2. Artemisinin-based combination } \\
\text { therapy }(\mathrm{ACT})\end{array}$ \\
\hline \multirow{2}{*}{ 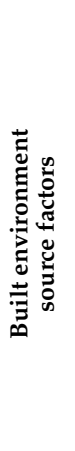 } & 1. Artificial breeding sites & $\begin{array}{l}\text { The mechanism of a SET requires a wall } \\
\text { that separates an interior from an exterior. } \\
\text { Although these tubes may not be used for } \\
\text { breeding sites, like drains, gutters, } \\
\text { swimming pools, or tire tracks [18], placing } \\
\text { a treated screen on these types of areas can } \\
\text { open new, innovative solutions to } \\
\text { preventing malaria in those sites, such as } \\
\text { electrostatic coating [53]. }\end{array}$ & $\begin{array}{l}\text { More larvae development results in } \\
\text { greater mosquito population density, } \\
\text { resulting in uneven distribution of } \\
\text { therapy needed and a greater number } \\
\text { of individuals at risk for disease. }\end{array}$ \\
\hline & 2. Urbanization & $\begin{array}{l}\text { Due to the scalability of eaves tubes, } \\
\text { there must be a focus on high-risk groups } \\
\text { that serve as priority, before the } \\
\text { intervention technologies are scaled to the } \\
\text { entire community [53]. }\end{array}$ & $\begin{array}{l}\text { Increased population results in } \\
\text { greater demand for this product. }\end{array}$ \\
\hline \multirow{2}{*}{ 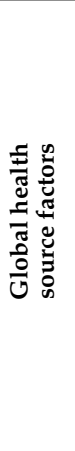 } & $\begin{array}{l}\text { 1. Low standard of living } \\
\text { (e.g., socioeconomic status) }\end{array}$ & $\begin{array}{l}\text { Low socioeconomic status (SES) to the } \\
\text { extent of homelessness within poverty may } \\
\text { occur in urban regions. Poverty is the } \\
\text { greatest risk factor towards malaria. } \\
\text { Poverty reduces opportunities to a formal } \\
\text { education, which reduces chances to get a } \\
\text { good job, recycling into increased } \\
\text { poverty [40]. }\end{array}$ & $\begin{array}{l}\text { Because there are problems related to } \\
\text { affordability and accessibility of this } \\
\text { drug, those of low SES who already } \\
\text { suffer the financial burden of disease } \\
\text { treatment are further at risk. }\end{array}$ \\
\hline & $\begin{array}{l}\text { 2. Geographic residence } \\
\text { (e.g., urban) }\end{array}$ & $\begin{array}{l}\text { Malaria is transmitted by different } \\
\text { Anopheles species, which can vary by } \\
\text { geographic environment. Some vectors are } \\
\text { more dominant than others. Therefore, } \\
\text { more SETs should be implemented in } \\
\text { regions with higher prevalence. }\end{array}$ & $\begin{array}{l}\text { Those in regions where the species of } \\
\text { Anopheles is more prevalent will } \\
\text { increase the demand, resulting in a } \\
\text { greater need for affordable and } \\
\text { accessible therapy drugs. }\end{array}$ \\
\hline \multirow{2}{*}{ 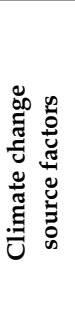 } & 1. Deforestation from land use & $\begin{array}{l}\text { Deforestation increases prevalence of the } \\
\text { malaria vector. Because buildings are made } \\
\text { by initial deforestation, the increase in } \\
\text { homes requiring SETs mirrors the increase } \\
\text { in the deforestation. }\end{array}$ & $\begin{array}{l}\text { Dispersal of the vector to different } \\
\text { geographic regions results in a greater } \\
\text { need to outsource the drug to new } \\
\text { communities, which causes difficulty } \\
\text { for those unable to afford or access } \\
\text { the drug. }\end{array}$ \\
\hline & $\begin{array}{l}\text { 2. Increased rainfall } \\
\text { (precipitation) }\end{array}$ & $\begin{array}{l}\text { Increased prevalence of the Anopheles vector } \\
\text { will result, causing greater need for SETs. }\end{array}$ & $\begin{array}{l}\text { More favorable habitat for } \\
\text { reproduction allows more generations } \\
\text { to develop. This can result in } \\
\text { antibiotic resistance. }\end{array}$ \\
\hline
\end{tabular}

The cells shaded in red indicate a negative causation in the propagation of malaria, green indicate a positive causation, and yellow cells indicate no (or unknown) relationship between the source factor and intervention strategy in question. The analysis was done in a reiterative manner, a core principle of the engineering design process; as the authors received new information, existing assessments were updated and new assessments were created where applicable. 


\section{Key Findings}

4.1. Broader Cross-Disciplinary Synergies are Critical to Managing the Interdependencies and Complexities of Malaria Risk Factors

There is data paucity with respect to actionable insights that can be used to characterize the magnitude and complexity of the problem. The nature of the problem involves a public health aspect, a built environment aspect, and a bridge between both fields. This would entail performing a rigorous analysis of source factors such as those tabulated in Tables $3-5$. The authors have identified impacts of climate change, growing concerns over population growth, and urbanization rates in the global south as priority convergence themes.

(a) Climate Change: New source factors are emerging because of climate change, which is known to trigger the development of environmental conditions that have adverse effects on the incidence of VBDs (see Figure 5). For example, abiotic factors such as wind pattern, precipitation pattern, and relative humidity can influence vector migration, seasonal population density, and the genetic composition of vector populations [54].

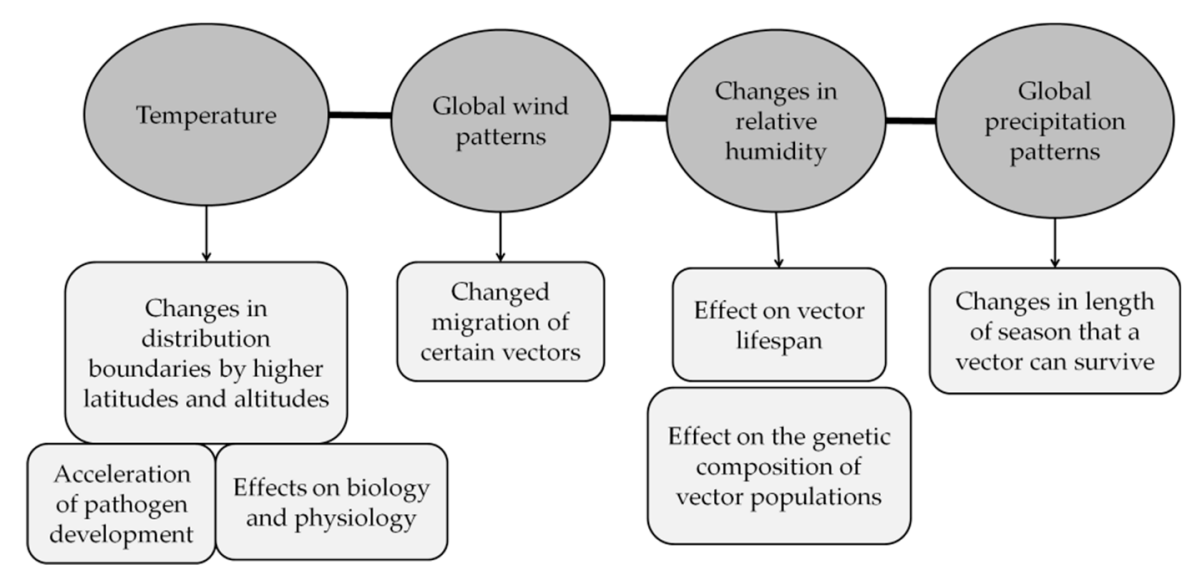

Figure 5. Direct effects of climate change on disease vectors adapted from Reference [54] Columbia Earth Institute Climate Nexus.

(b) Population increase: The complex and complicated nature between rapid population growth and the risk of malaria transmission through managing built environment-related factors has been depicted in Figure 6. A rapid increase in population results in increased exploitation of resources in a way that contributes to climate change. Human activities, such as agriculture and transportation technology, compound the problem of greenhouse gas emissions by contaminating the atmosphere with pollutants. These risks increase the number and severity of human health complications, such as respiratory and cardiovascular illnesses, thereby compromising their immunity to other diseases. Air pollution also has a direct bearing on prevailing temperature conditions and can increase precipitation to levels outside of the known patterns that can result in flooding. An increase in warm or hot days coupled with flooding increases the number of breeding sites and the speed of maturation for mosquito larvae [55].

A rapid population growth results in increased demand for housing. The rapid population growth creates a problem for congested urban areas. An increase in population density in such areas triggers a need for land use changes, which can result in previously forested areas being cleared to make room for human habitation. The demand for new construction creates more opportunities for vector-human interaction. This association, propagated by factors like debris and stagnant water pools, can cause more VBDs as more land is used for construction. As populations in villages and towns trend upwards with the building of dams, humans will get closer to mosquito breeding grounds [55]. This increase in infection will persist because of the complex and complicated nature of the relationship between the built environment and malaria. 


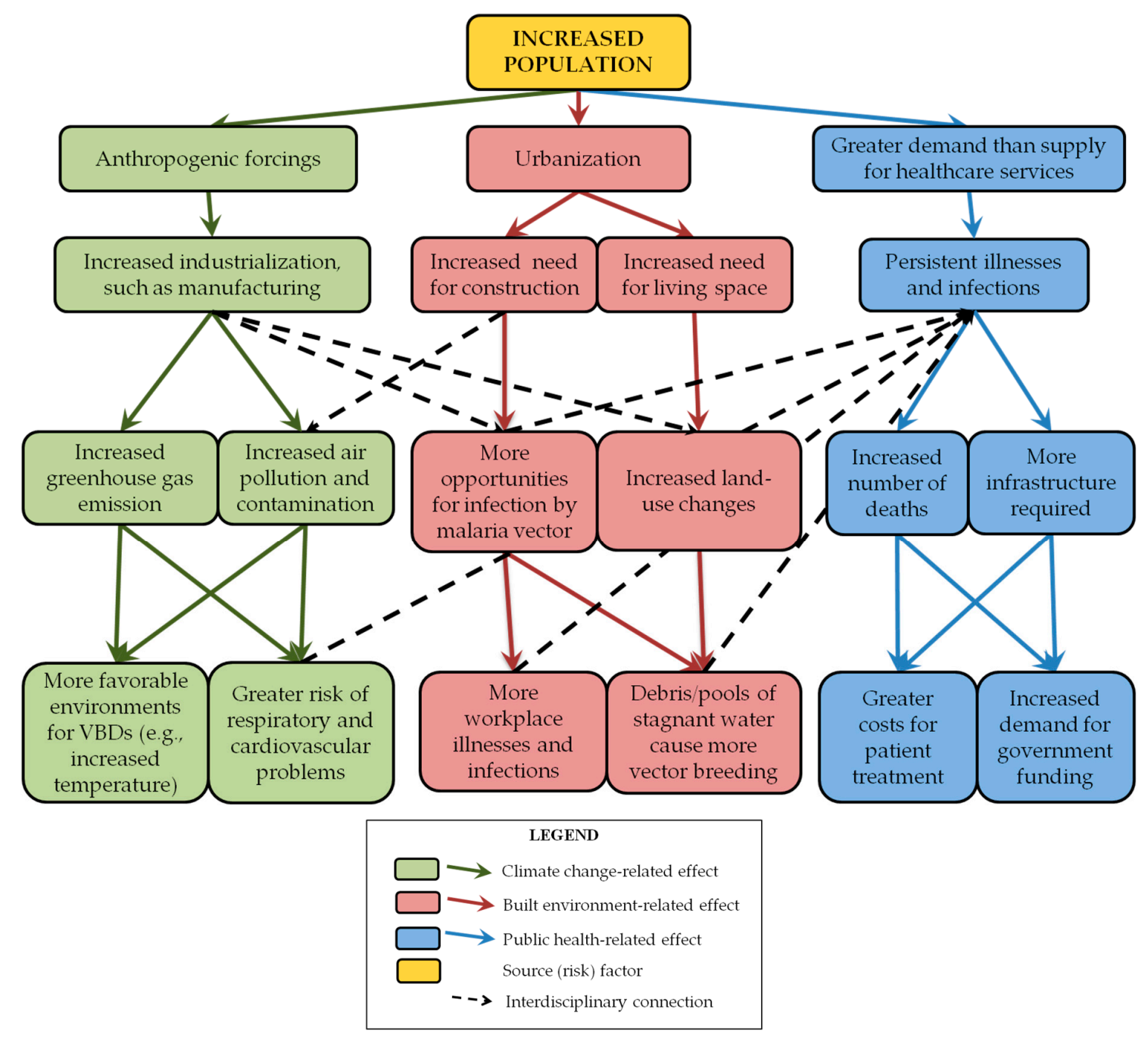

Figure 6. Source factor propagation scenario.

The analyzed data also established that an increase in population can compound health problems through increased human-human contact and human-environment contact. Rapid population growth rates also create a greater demand for healthcare services, which places additional financial pressures on healthcare systems in resource-constrained malarious regions. There is also an increase in the cost of healthcare that can be attributed to rapid population growth rates through the sheer increase in absolute numbers. This may partially explain the escalating expenses associated with malaria prevention referenced in the introductory section.

Anthropogenic activities traditionally associated with climate change, such as coal mining, increased energy consumption, and trade, have a direct relationship with the built environment. A rapidly growing population increases the demand for new construction. The growing volume of newly constructed buildings contributes to deforestation through the associated demand for timber. Increased anthropogenic activities also create greater opportunities for workplace illnesses, which in turn result in additional financial pressures on public health services.

Other significant population-related factors include the social determinants of health, such as food security, cultural practice, spiritual beliefs, attitude and opinions, government advocacy, urban planning policy, public-private partnerships, and healthcare access. A sociocultural factor that influences the prevalence of malaria, particularly in children, is the patriarchal nature of families. Social stratification results in the most vulnerable groups having lower access to the nutritious food that is required to boost their immunity [40]. In areas where food is scarce, if the fathers hold the 
right to eating first, children under the age of 5 can end up being malnourished, leaving them at a higher risk of contracting malaria. From a built environment perspective, homes with more vulnerable groups can be identified and given priority in interventions such as minimizing the ease with which mosquitoes can access the buildings.

Other known barriers include the lack of access to public health information. Some communities may have limited access to information in print or electronic media or have inhibitions that prevent them from accessing such information. Adefemi et al. [40] noted that, in some rural communities, the presence of malaria under the compass of ill health is often treated as a symptom of being possessed by demons or evil spirits. It is important to understand these things, as they will have a direct bearing on whether or not members of community embrace any proposed modification to their houses. The primary authors have observed that in some parts of Kenya, bed nets are using to protect young plants from being eaten by goats, suggesting that they assign a lower value to preventing being bitten by mosquito bites.

(c) Rapid urbanization: Half of humanity, 3.5 billion people, live in cities [56], and it is estimated that by 2030, almost 60 percent of the global population will live in urban areas. According to 2018 UN population projections, the parts of the world that are more adversely affected by malaria are also going to experience the highest urbanization rates in the next several decades. In fact, there is a strong, positive correlation between increased urbanization and an increased number of malaria infections [57]. This is evident from the reported trends for malaria-prone regions in urban Kenya and Tanzania. Based on UN projections, Tanzania's population is expected to grow by 22\% between 2014 and 2050, peaking at an estimated 68.5 million people [58]. During the same timeframe, Kenya's urbanized population is expected to grow by $19 \%$, resulting in an estimated 42.6 million urban inhabitants. Rapid urbanization comes with increased construction activities because of growing demands for housing, resulting in the problems discussed in the previous subsection.

There is a growing urban slum population in both Kenya and Tanzania that is expected to increase because the demand for new housing has greatly surpassed the supply from the formal construction sector. This is exemplified by Tanzania's estimated housing deficit of 3 million [59]. The low-income population with unmet demands ends up being inadequately housed in the slums and other poorly serviced settlement areas. There is a positive correlation between the growth of slums/poorly serviced settlement areas and the risk of malaria. Slum conditions, such as poorly monitored land use and urban agricultural practices, result in higher mosquito-biting rates [60]. Slums and poorly serviced settlement areas have poor quality housing, unpaved roads, and a lack of adequate infrastructure for waste water and sewer. The inhabitants also have limited access to healthcare services. These factors, combined with rapid urban expansion and ever-increasing city boundaries, result in an increased transmission of malaria that town planners are unable to keep up with [20]. Built environment professionals need to create measures to control the spread of malaria in the existing slum upgrading efforts.

\subsection{There Is an Opportunity to Catalyze Transformative Impact in the Mitigation of the Risk of Malaria through Leveraging the Life Cycle of Buildings}

The mitigation of the risk of VBDs should be formally defined as one of the design objectives for building projects in countries with a high incidence of malaria. This will require intentionality with respect to increasing awareness on the different ways through which the main activities undertaken throughout the life cycle of a construction project can propagate the spread of malaria. The design team is either directly responsible for or uniquely positioned to influence decision making in each of the phases. The listing below gives examples of specific ways through which their decisions can contribute to efforts directed at mitigating the risk of malaria:

(1) Preliminary Phase: Selection of a site near an open surface water body may increase the number of breeding sites for the malaria vector;

(2) Conceptual Design: The placement and size of openings as well as the orientation of the building envelopes affects the vector accessibility both into and out of the building; 
(3) Detailed Design: Certain types of material on housing features, such as mud walls, thatched roofs, and earth, sand, dung, and stone flooring, increase vector attraction into the site [61];

(4) Construction: Excavation work results in opportunities for several pools of stagnant water to form-such pools are ideal breeding grounds for mosquitoes;

(5) Facilities Management: Drains and ditches are common habitats for mosquitoes to breed [62]; poorly installed pipes and drain blockage can lead to poor sanitation or reduced water flow. The accumulated stagnant water can become a favorable habitat, and;

(6) End of Life/Disuse: Construction and demolition waste contributes to the environmental problem of landfills.

The largest window of opportunity for making an impact in a cost-effective and efficient manner is during the conceptual design phase [62] (see Figure 7). There is a cost associated with changes made in subsequent phases that increases exponentially with time. It is, therefore, more beneficial to engage with professionals responsible for making critical design decisions during the formative stage of a project.

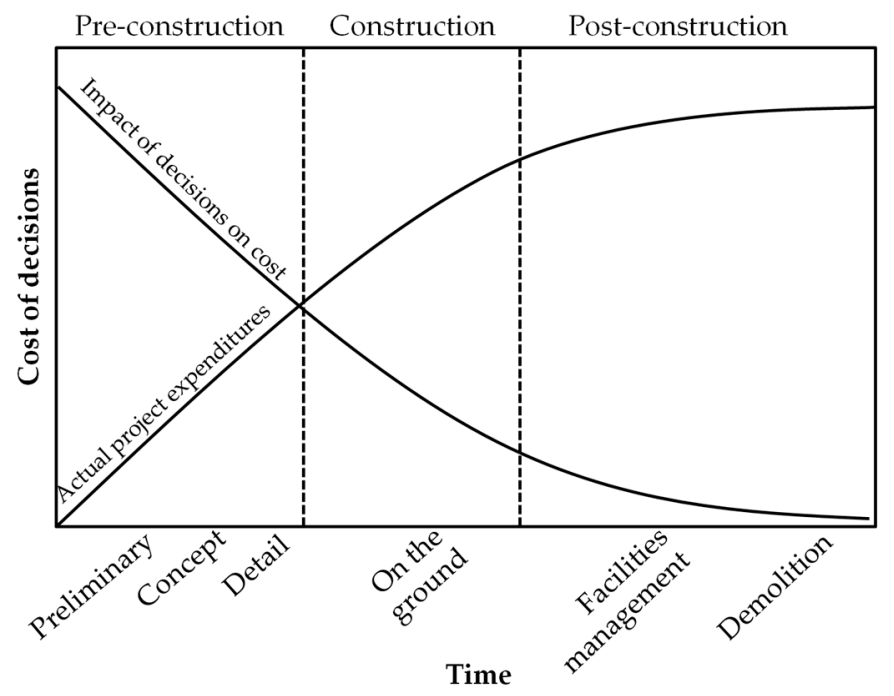

Figure 7. Cost-benefit curve-early decision making in construction life cycle adapted from Reference [63], 2018 American Institute of Steel Construction.

The extent to which built environment-related factors can be used to mitigate the spread of malaria during the construction life cycle requires a deeper understanding of several risk factors present during the entire construction life cycle. Changes in global wind pattern and increased rainfall are examples of risk factors that propagate the spread of the disease. The risk of malaria infection is higher at night, given that the Anopheles mosquitoes in SSA mainly bite between 10 p.m. and 4 a.m., when most people are indoors. Weather-related factors, such as increased precipitation, relative humidity, and temperature conditions, can also create a more suitable habitat for the malaria vector [54].

A study focusing on land use and malaria transmission in Uganda found that for every $1{ }^{\circ} \mathrm{C}$ increase in average minimum temperature, that there was a $77 \%$ increase in Anopheles gambiae per each model house [41]. When such favorable conditions coincide with the construction phase of a project, the breeding potential for malaria-causing mosquitoes also increases significantly. The construction phase is characterized by pools of stagnant water developing in areas of intense excavation [37] and areas with earth removal work [64]. The water source from these pools can have leakage from temporary water supply points or improperly drained storm water [65].

Some of the ways through which the built environment contributes to the risk of malaria transmission becomes more apparent during the facility use phase. Malaria-causing mosquitoes access buildings through inlets and outlets; these features are included in the design of the building 
envelope to allow air exchange between the exterior and the interior. Malaria mitigation initiatives are directed at minimizing the ease with which mosquitoes access the interior of the buildings by focusing on reducing the size and number of openings [66]. It is critical to engage built environment design professionals to ensure that the desired building modifications do not result in undesirable effects, as the targeted buildings rely on passive heating and cooling strategies.

Because indoor air quality (IAQ) and the thermal comfort of building occupants predicate on having optimal air exchanges between the inside and outside, changes to the openings can result in unfavorable conditions for humans [67]. Poor IAQ can increase the risk of respiratory diseases [68]. Maintaining a proper IAQ is also important for managing air-borne pathogens. Reducing air exchanges has a direct impact on the choices and habits of building occupants-if openings are modified to the point where they experience thermal discomfort, they spend more time outdoors. The primary author has observed that occupants spend most of the evening hours outdoors because of thermal discomfort indoors in some of the malarious parts of Kenya and Tanzania. They thus have a much higher risk of being bitten by malaria-causing mosquitoes because this is also a time when the latter is very active. It is also known that poor IAQ can increase the risk of respiratory diseases [68].

Ensuring that optimal ventilation rates are attained requires an in-depth understanding of the building as an integrated system. Decisions such as the size, exact location, and number of openings must be aligned with the principles of building physics that influence the adequacy of passive ventilation. Mitigating the risk of malaria from a built environment perspective is a complex undertaking. Each decision has many associated linkages and interdependencies. The existing building envelop modifications which may have been performed without close synergies with the relevant built environment professionals can compromise the primary factors that underpin the definition of a healthy building_-indoor air quality.

\subsection{There Is a Need for a Decision Support System That Can Be Used by Built Environment Professionals to Manage the Interdependencies and Complexities of Malaria Risk Factors}

The preceding subsections have underscored the need for information to be shared across different disciplines. The authors contend that this need can be addressed through developing a knowledge management framework with the features depicted in Figure 8. This conceptual architecture for a decision support system is based on a synthesis of the identified sources factors for the risk of VBDs.

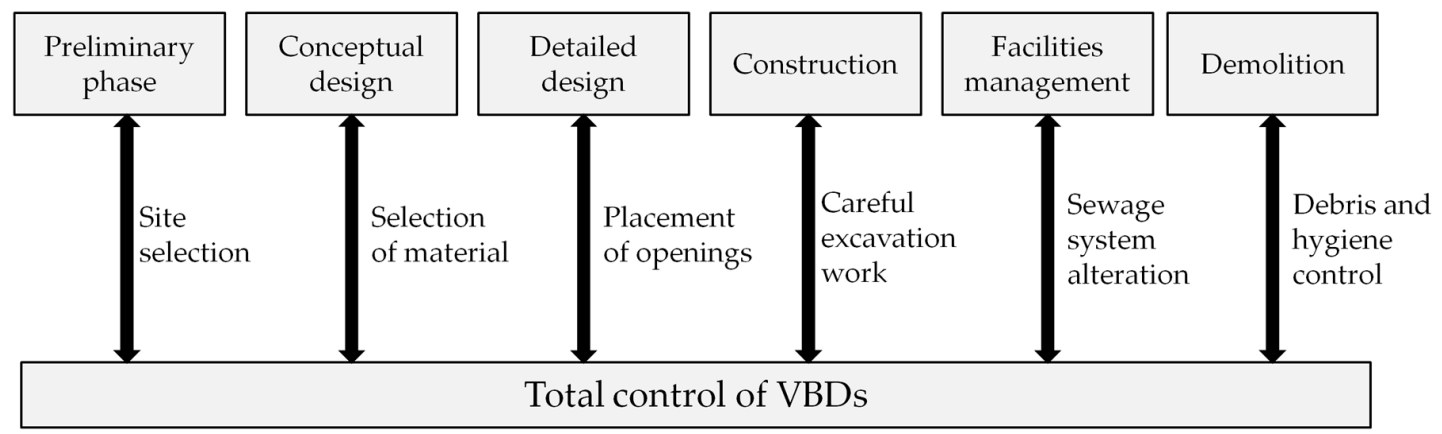

Figure 8. A decision support system for built environment professionals.

Site selection is an important course factor that can be leveraged in malaria mitigation efforts. Project sites that have close proximity to dams, buildings that are dilapidated, and swamps increase disease prevalence. Creating a systematic procedure and checklist to capture all source factors can encourage the design team and building owners to consider the surroundings of potential project sites before any decision that cannot be easily reversed is made.

The appropriate selection of materials can address the observed problem of buildings having been constructed using traditional materials and becoming more susceptible to mosquito intrusion. It is worth noting that traditional materials are environmentally more sustainable, considering their 
carbon footprint. The authors recommend that rather than encouraging their disuse, efforts should be invested in researching ways through which material science can be used to address the reasons why mosquitoes prefer buildings that have been constructed using traditional materials.

The existing knowledge on specific ways through which openings can increase the ease with which mosquitoes can access a home should inform what is largely a natural ventilation-driven optimization strategy used to specify the size and location of windows, doors, and vents in new building envelopes. Stagnant water that forms when rain water accumulates in excavated areas increases the number of favorable sites for mosquito larvae to mature. Having a robust strategy for promptly draining stagnant pools can be factored into existing dewatering strategies. Foundation work usually includes a budget for pumping out water during excavation to allow for the construction of foundation elements following heavy rains.

Retrofits, repairs, and building modifications focused on malaria mitigation should consider the impact of indoor air quality and human comfort on the risk of malaria. The facilities management phase also models successful VBD control when the material of construction and surrounding moisture are considerations. A knowledge management framework would provide value by sharing proper techniques for installation and appropriate materials for piping in order to ensure a long lifespan and minimal need for repair.

The impact of the demolition of a building on the risk of VBD can vary significantly depending on an interest in salvaging some of the material. In general, construction and demolition waste often end up in landfills, which presents several environmental problems, including the creation of favorable breeding conditions for mosquitoes. There is a growing interest in shifting the construction industry to a more circular economy through encouraging both recycling and upcycling. The proposed decision support systems can leverage this interest to promote awareness on the link between how demolition waste is managed and the risk of VBDs.

\section{Discussion and Further Work}

This paper presented findings from research directed at designing and developing a decision support tool for mitigating the spread of vector-borne diseases (VBDs) through delivering actionable insights to built environment professionals. The paper focused specifically on the opportunity to minimize the impact of built environment-related risks factors for malaria through a proposed decision support tool that encourages discussions on the trade-offs and the wider implications of choices across the different subsectors during the entire life cycle of a building.

The authors are promoting a "health-centric" approach to designing and constructing the built environment, as encouraged by the New Urban Agenda (NUA) [69]. Urbanization is one of the leading global trends of the 21st century that has a significant impact on health. By 2050, over 70\% of the world's population will live in cities [56]. In developing countries, more than $50 \%$ of the urban population suffers from inadequate housing and transport, poor sanitation and waste management, and air quality failing WHO guidelines. Urban waste mismanagement perpetuates the transmission of VBDs, including malaria and dengue fever, as well as Zika and Ebola. There is an urgent need to provide equitable access to infrastructure and to upgrade informal settlements worldwide. The NUA, a global, nonbinding agenda, adopted during the October 2016 Habitat III convening in Quito, Ecuador [17], escalates the need for more convergence between health and the built environment. NUA recognizes that the shape and form of urban development influences the health of city residents. The professionals who design, plan, build, and govern cities exercise great influence over the basic ingredients of a healthy life, including access to decent housing, clean air and water, nutritious food, safe transport and mobility, opportunities for physical activity, and protection from injurious risks and toxic pollutants [69]. An urban space that offers these fundamental, health-enabling conditions can dramatically reduce the incidence of and costs associated with a wide range of diseases, including VBDs.

Although health is the pulse of the NUA, there are no details on specific actions [69]. There was an emphasis on the importance of public, private, and civil society cooperation in efforts directed at 
operationalizing the NUA during the ninth session of the World Urban Forum (WUF9), which took place in Kuala Lumpur, Malaysia in February 2018. During the Technology and Innovation for Development session, there was consensus that one of the critical areas of need was filling the local-level "data gap". Habitat III's collective vision of sustainable, livable, and economically vibrant cities encourages urban decision-makers to fully assess the health risks and opportunities posed by their policies and programs, and measure their effects. Operationalizing this vision will require increased cooperation between different stakeholders to capitalize on synergies and cross-sectoral coordination to ensure policy coherence that is required to achieve systemic change. This will require comprehensive discussions by the different stakeholders on the trade-offs and the wider implications of each stakeholder's choices. The authors will use a case study approach to propose a health-centric decision support tool that encourages built environment professionals to make design choices that mitigate the spread of malaria.

In its 2016 comprehensive study of the interface between buildings and health, Reference [70] Dodge Analytics identified the need for more research and data on how to improve building health impacts and public awareness campaigns. In addition, the economic constraints associated with generating public awareness should be noted. Proper economic measures, such as having the resources necessary to create an environment protective against malaria, are key factors towards enhancing the impact of public awareness on malaria mitigation. The analysis done as part of this research identified how this need can be addressed through the design and development of a decision support system for the built environment professionals. As part of further work, the authors will develop a prototype decision support system whose functionality will be designed, tested, and validated through interactions with selected, East Africa-based stakeholders. The focus here will be designing strategies through which relevant information could be pushed and/or pulled into decision-making processes by built environment professionals during the design phase.

Because malaria is a complex problem, it must be addressed through both a bottom-up and top-down approach. In addition to working directly with built environment professionals, as outlined in the preceding paragraph, there will be a need for the proposed knowledge management platform to have linkages to portals where professionals working in institutions and organizations that have a regional, national, and global influence exchange information. These include: (1) public health forums such as those managed by WHO, PMI, and USAID, which provide worldwide funding and support for actionable intervention methods, like SETs, ITNs, and Indoor Residual Spraying (IRSs); (2) government programs in, for example, Ministry of Health initiatives that have a presence at both the national and regional level; (3) professional organizations such as the Architectural Association of Kenya, which have the convening power required to disseminate information at scale through conferences, workshops, and continued professional educational programs; and (4) donor organizations and funding agencies such as the Bill and Melinda Gates Foundation, which are increasingly advocating for cross-disciplinary synergies in the fight against malaria. The proposed knowledge management platform will be designed and developed in subsequent efforts.

While the presented study is important, this paper does not address the cultural ideas of the built environment. Each culture understands and perceives the suggested recommendations differently, so it is crucial to bridge the empirical, historical knowledge that exists within social experience and ecological structures of the locations under study with the knowledge gained from literature to generate the most sustainable form of impact. The study recognizes economic constraints have a domino effect on making a sustainable social development and vector-free built environment. Therefore, the proposed built environment strategy will be more successful if performed in conjunction with risk mitigation efforts, such as poverty alleviation initiatives, educational campaigns, and sustainable public health policies. These cultural nuances will be investigated further and discussed in a subsequent publication.

Author Contributions: Conceptualization, E.O. and S.P.; Review of Closely Related Work, E.O. and S.P.; Methodology, E.O. and S.P.; Data curation, E.O. and S.P.; Formal analysis, E.O. and S.P.; Writing-original draft, E.O. and S.P.; Writing-review and editing, E.O., S.P. and D.W. 
Funding: This research received no external funding.

Conflicts of Interest: The authors declare no conflicts of interest.

\section{References}

1. World Health Organization. Fact Sheet about Malaria. Available online: https://www.who.int/malaria/en/ (accessed on 30 September 2017).

2. HIV/AIDS Data and Statistics. Available online: https://www.who.int/hiv/data/en/ (accessed on 30 September 2017).

3. World Health Organization. Global Tuberculosis Report. Available online: https://www.who.int/tb/ publications/global_report/MainReport_18Sept2018.pdf (accessed on 30 September 2018).

4. World Health Organization. Dengue and Severe Dengue. Available online: https://www.who.int/newsroom/fact-sheets/detail/dengue-and-severe-dengue (accessed on 30 September 2018).

5. World Health Organization. Global Leprosy Programme. Available online: http://www.searo.who.int/ entity/global_leprosy_programme/en/ (accessed on 30 September 2018).

6. World Health Organization. Ebola Virus Disease. Available online: https://www.who.int/news-room/factsheets / detail/ebola-virus-disease (accessed on 30 September 2018).

7. World Health Organization. Global Technical Strategy for Malaria 2016-2030. Available online: https: //www.who.int/malaria/areas/global_technical_strategy/en/ (accessed on 30 September 2018).

8. World Health Organization. World Malaria Report 2016. Available online: https://www.who.int/malaria/ publications/world-malaria-report-2016/report/en/ (accessed on 2 November 2018).

9. Roser, M.; Ritchie, H. Malaria. Available online: https://ourworldindata.org/malaria (accessed on 30 September 2018).

10. The Global Fund. Financials. Available online: https://www.theglobalfund.org/en/financials/ (accessed on 14 April 2018).

11. World Health Organization. World Malaria Report 2017. Available online: https://www.who.int/malaria/ publications/world-malaria-report-2017/en/ (accessed on 2 November 2018).

12. World Health Organization. World Malaria Report 2010. Available online: https://www.who.int/malaria/ world_malaria_report_2010/en/ (accessed on 2 November 2018).

13. Sustainable Development Goals Knowledge Platform. Transforming Our World: The 2030 Agenda for Sustainable Development. Available online: https://sustainabledevelopment.un.org/post2015/ transformingourworld (accessed on 1 November 2018).

14. World Health Organization. Sustainable Cities: Health at the Heart of Urban Development. Available online: https: / / www.who.int/sustainable-development/cities/Factsheet-Cities-sustainable-health.pdf (accessed on 30 October 2018).

15. United Nations General Assembly. Draft outcome document of the United Nations Conference on Housing and Sustainable Urban. Development (Habitat III). In Proceedings of the Habitat III Conference, Quito, Ecuador, 17-20 October 2016.

16. Tusting, L.S.; Ippolito, M.M.; Willey, B.A.; Kleinschmidt, I.; Dorsey, G.; Gosling, R.D.; Lindsay, S.W. The evidence for improving housing to reduce malaria: A systematic review and meta-analysis. Malar. J. 2015, 14, 209. [CrossRef] [PubMed]

17. Menger, D.J.; Otieno, B.; de Rijk, M.; Mukabana, W.R.; van Loon, J.J.; Takken, W. A push-pull system to reduce house entry of malaria mosquitoes. Malar. J. 2014, 13, 119. [CrossRef] [PubMed]

18. De Silva, P.; Marshall, J. Factors Contributing to Urban. Malaria Transmission in Sub-Saharan Africa: A Systematic Review. J. Trop. Med. 2012, 2012, 10. [CrossRef] [PubMed]

19. Gamage-Mendis, A.C.; Carter, R.; Mendis, C.; De Zoysa, A.P.; Herath, P.R.; Mendis, K.N. Clustering of malaria infections within an endemic population: Risk of malaria associated with the type of housing construction. Am. J. Trop. Med. Hyg. 1991, 45, 77-85. [CrossRef] [PubMed]

20. Malaria. Available online: https://www.cdc.gov/malaria/about/history/panama_canal.html\# (accessed on 10 October 2017).

21. Ogoma, S.B.; Kannady, K.; Sikulu, M.; Chaki, P.P.; Govella, N.J.; Mukabana, W.R.; Killeen, G.F. Window screening, ceilings and closed eaves as sustainable ways to control malaria in Dar es Salaam, Tanzania. Malar. J. 2009, 8, 221. [CrossRef] [PubMed] 
22. Tizifa, T.A.; Kabaghe, A.N.; McCann, R.S.; van den Berg, H.; Van Vugt, M.; Phiri, K.S. Prevention Efforts for Malaria. Curr. Trop. Med. Rep. 2018, 5, 41-50. [CrossRef]

23. Mitsakakis, K.; Hin, S.; Müller, P.; Wipf, N.; Thomsen, E.; Coleman, M.; Zengerle, R.; Vontas, J.; Mavridis, K. Converging Human and Malaria Vector Diagnostics with Data Management towards an Integrated Holistic One Health Approach. Int. J. Environ. Res. Public Health 2018, 15, 259. [CrossRef]

24. Mgone, C.S. Strengthening of the clinical research capacity for malaria: A shared responsibility. Malar. J. 2010, 9, S5. [CrossRef]

25. Marshall, J.M.; Touré, M.B.; Traore, M.M.; Famenini, S.; Taylor, C.E. Perspectives of people in Mali toward genetically-modified mosquitoes for malaria control. Malar. J. 2010, 9, 128. [CrossRef]

26. Atkinson, J.A.; Vallely, A.; Fitzgerald, L.; Whittaker, M.; Tanner, M. The architecture and effect of participation: A systematic review of community participation for communicable disease control and elimination. Implications for malaria elimination. Malar. J. 2011, 10, 225. [CrossRef]

27. Wang, S.J.; Lengeler, C.; Smith, T.A.; Vounatsou, P.; Cissé, G.; Tanner, M. Rapid Urban Malaria Appraisal (RUMA) III: Epidemiology of urban malaria in the municipality of Yopougon (Abidjan). Malar. J. 2006, 5, 29. [CrossRef] [PubMed]

28. Qi, Q.; Guerra, C.A.; Moyes, C.L.; Elyazar, I.A.F.; Gething, P.W.; Hay, S.I.; Tatem, A.J. The effects of urbanization on global Plasmodium vivax malaria transmission. Malar. J. 2012, 11, 403. [CrossRef]

29. Vajda, E.A.; Webb, C.E. Assessing the Risk Factors Associated with Malaria in the Highlands of Ethiopia: What Do We Need to Know? Trop. Med. Infect. Dis. 2017, 2, 4. [CrossRef] [PubMed]

30. Hausmann-Muela, S.; Eckl, J. Re-imagining malaria-A platform for reflections to widen horizons in malaria control. Malar. J. 2015, 14, 180. [CrossRef] [PubMed]

31. Ocampo, A.J.; Chunara, R.; Brownstein, J.S. Using search queries for malaria surveillance, Thailand. Malar. J. 2013, 12, 390. [CrossRef] [PubMed]

32. Tatem, A.J.; Huang, Z.; Narib, C.; Kumar, U.; Kandula, D.; Pindolia, D.K.; Smith, D.L.; Cohen, J.M.; Graupe, B.; Uusiku, P.; et al. Integrating rapid risk mapping and mobile phone call record data for strategic malaria elimination planning. Malar. J. 2014, 13, 52. [CrossRef] [PubMed]

33. Semenza, J.C. Prototype Early Warning Systems for Vector-Borne Diseases in Europe. Int. J. Environ. Res. Public Health 2015, 12, 6333-6351. [CrossRef] [PubMed]

34. Ninphanomchai, S.; Chansang, C.; Hii, Y.L.; Rocklöv, J.; Kittayapong, P. Predictiveness of Disease Risk in a Global Outreach Tourist Setting in Thailand Using Meteorological Data and Vector-Borne Disease Incidences. Int. J. Environ. Res. Public Health 2014, 11, 10694-10709. [CrossRef]

35. Reiter, P. Global Warming and Malaria: Knowing the Horse before Hitching the Cart. Malar. J. 2008, 7, S3. [CrossRef]

36. Klinkenberg, E.; McCall, P.J.; Wilson, M.D.; Amerasinghe, F.P.; Donnelly, M.J. Impact of urban agriculture on malaria vectors in Accra, Ghana. Malar. J. 2008, 7, 151. [CrossRef]

37. Hay, S.I.; Cox, J.; Rogers, D.J.; Randolph, S.E.; Stern, D.I.; Shanks, G.D.; Myers, M.F.; Snow, R.W. Climate change and the resurgence of malaria in the East African highlands. Nature 2002, 415, 905-909. [CrossRef] [PubMed]

38. Adefemi, K.; Awolaran, O.; Wuraola, C. Social and environmental determinants of malaria in under five children in Nigeria: A review. Int. J. Commun. Med. Public Health 2015, 2, 345-350. [CrossRef]

39. Negev, M.; Paz, S.; Clermont, A.; Pri-Or, N.G.; Shalom, U.; Yeger, T.; Green, M.S. Impacts of Climate Change on Vector Borne Diseases in the Mediterranean Basin-Implications for Preparedness and Adaptation Policy. Int. J. Environ. Res. Public Health 2015, 12, 6745-6770. [CrossRef] [PubMed]

40. Zhou, G.; Afrane, Y.A.; Vardo-Zalik, A.M.; Atieli, H.; Zhong, D.; Wamae, P.; Himeidan, Y.E.; Minakawa, N.; Githeko, A.K.; Yan, G. Changing Patterns of Malaria Epidemiology between 2002 and 2010 in Western Kenya: The Fall and Rise of Malaria. PLoS ONE 2011, 6, 5. [CrossRef] [PubMed]

41. Lindblade, K.A.; Walker, E.D.; Onapa, A.W.; Katungu, J.; Wilson, M.L. Land use change alters malaria transmission parameters by modifying temperature in a highland area of Uganda. Trop. Med. Int. Health 2000, 5, 263-274. [CrossRef] [PubMed]

42. Tonnang, H.E.; Kangalawe, R.Y.; Yanda, P.Z. Predicting and mapping malaria under climate change scenarios: The potential redistribution of malaria vectors in Africa. Malar. J. 2010, 9, 111. [CrossRef] [PubMed] 
43. Edlund, S.; Davis, M.; Douglas, J.V.; Kershenbaum, A.; Waraporn, N.; Lessler, J.; Kaufman, J.H. A global model of malaria climate sensitivity: Comparing malaria response to historic climate data based on simulation and officially reported malaria incidence. Malar. J. 2012, 11, 331. [CrossRef]

44. Walls, K.L.; Boulic, M.; Boddy, J.W.D. The Built Environment-A Missing Cause of the Causes of Non-Communicable Diseases. Int. J. Environ. Res. Public Health 2016, 13, 956. [CrossRef]

45. Lindsay, S.W.; Emerson, P.M.; Charlwood, J.D. Reducing malaria by mosquito-proofing houses. Trends Parasitol. 2002, 18, 510-514. [CrossRef]

46. Lindsay, S.W.; Jawara, M.; Paine, K.; Pinder, M.; Walraven, G.E.L.; Emerson, P.M. Changes in house design reduce exposure to malaria mosquitoes. Trop. Med. Int. Health 2003, 8, 512-517. [CrossRef]

47. Allen, L.K.; Hetherington, E.; Manyama, M.; Hatfield, J.M.; van Marle, G. Using the social entrepreneurship approach to generate innovative and sustainable malaria diagnosis interventions in Tanzania: a case study. Malar. J. 2010, 9, 42. [CrossRef] [PubMed]

48. Tusting, L.S.; Willey, B.; Lines, J. Building malaria out: Improving health in the home. Malar. J. 2016, 15, 320. [CrossRef] [PubMed]

49. Atieli, H.; Menya, D.; Githeko, A.; Scott, T. House design modifications reduce indoor resting malaria vector densities in rice irrigation scheme area in western Kenya. Malar. J. 2009, 8, 108. [CrossRef] [PubMed]

50. Njau, R.J.; de Savigny, D.; Gilson, L.; Mwageni, E.; Mosha, F.W. Implementation of an insecticide-treated net subsidy scheme under a public-private partnership for malaria control in Tanzania-Challenges in implementation. Malar. J. 2009, 8, 201. [CrossRef] [PubMed]

51. Waite, J.L.; Lynch, P.A.; Thomas, M.B. Eave tubes for malaria control in Africa: A modelling assessment of potential impact on transmission. Malar. J. 2016, 15, 449. [CrossRef] [PubMed]

52. Tusting, L.S.; Bottomley, C.; Gibson, H.; Kleinschmidt, I.; Tatem, A.J.; Lindsay, S.W.; Gething, P.W. Housing Improvements and Malaria Risk in Sub-Saharan Africa: A Multi-Country Analysis of Survey Data. PLoS Med. 2017, 14, e1002234. [CrossRef]

53. Okumu, F. The paradigm of eave tubes: Scaling up house improvement and optimizing insecticide delivery against disease-transmitting mosquitoes. Malar. J. 2017, 16, 207. [CrossRef]

54. Climate Risk and Spread of Vector-Borne Diseases. Available online: https://climatenexus.org/climateissues/health/climate-change-and-vector-borne-diseases/ (accessed on 22 September 2016).

55. Nabi, S.A.; Qader, S.S. Is Global Warming likely to cause an increased incidence of Malaria? Libyan J. Med. 2009, 4, 9-16. [CrossRef]

56. United Nations. Goal 11: Make Cities Inclusive, Safe, Resilient and Sustainable. Available online: https: / / www.un.org/sustainabledevelopment/cities/ (accessed on 14 April 2018).

57. Donnelly, M.J.; McCall, P.J.; Lengeler, C.; Bates, I.; D’Alessandro, U.; Barnish, G.; Konradesn, F.; Klinkenberg, E.; Townson, H.; Trape, J.F.; et al. Malaria and urbanization in sub-Saharan Africa. Malar. J. 2005, 4, 12. [CrossRef]

58. The World Bank. Population, Total. Available online: https://data.worldbank.org/indicator/SP.POP.TOTL (accessed on 14 April 2018).

59. Barnes, R. Tanzania's Housing Deficit at Three Million Units. Available online: https:/ / constructionreviewonline. com/2015/05/tanzanias-housing-deficit-at-three-million-units/ (accessed on 2 October 2018).

60. Patz, J.A.; Daszak, P.; Tabor, G.M.; Aguirre, A.A.; Pearl, M.; Epstein, J.; Wolfe, N.D.; Kilpatrick, A.M.; Foufopoulos, J.; Molyneux, D.; et al. Unhealthy landscapes: Policy recommendations on land use change and infectious disease emergence. Environ. Health Perspect. 2004, 112, 1092-1098. [CrossRef]

61. Wanzirah, H.; Tusting, L.S.; Arinaitwe, E.; Katureebe, A.; Maxwell, K.; Rek, J.; Bottomley, C.; Staedke, S.G.; Kamya, M.; Dorsey, G.; et al. Mind the Gap: House Structure and the Risk of Malaria in Uganda. PLoS ONE 2015, 10, e0117396. [CrossRef] [PubMed]

62. Mattah, P.A.; Futagbi, G.; Amekudzi, L.K.; Mattah, M.M.; de Souza, D.K.; Kartey-Attipoe, W.D.; Bimi, L.; Wilson, M.D. Diversity in breeding sites and distribution of Anopheles mosquitoes in selected urban areas of southern Ghana. Parasites Vectors 2017, 10, 1. [CrossRef] [PubMed]

63. Why Steel. Available online: https://www.aisc.org/why-steel/resources/project-delivery-methods/ (accessed on 14 April 2018).

64. Lipscomb, H.J.; Glazner, J.E.; Bondy, J.; Guarini, K.; Lezotte, D. Injuries from slips and trips in construction. Appl. Ergon. 2006, 37, 267-274. [CrossRef] [PubMed] 
65. Mekonnen, Y.; Haile, M.; Ghebreyesus, T.A.; Witten, K.A.; Getachew, A.; Byass, P.; Lindsay, S.W. Can source reduction of mosquito larval habitat reduce malaria transmission in Tigray, Ethiopia? Trop. Med. Int. Health. 2005, 10, 12. [CrossRef]

66. Sternberg, E.D.; Ng'habi, K.R.; Lyimo, I.N.; Kessy, S.T.; Farenhorst, M.; Thomas, M.B.; Knols, B.G.J.; Mnyone, L.L. Eave tubes for malaria control in Africa: Initial development and semi-field evaluations in Tanzania. Malar. J. 2016, 15, 447. [CrossRef] [PubMed]

67. Huizenga, C.; Abbaszadeh, S.; Zagreus, L.; Arens, E.A. Air quality and thermal comfort in office buildings: Results of a large indoor environmental quality survey. Indoor Environmental Quality (IEQ). Proc. Healthy Build. 2006, 3, 393-397.

68. Ezzati, M.; Kammen, D.M. The Health Impacts of Exposure to Indoor Air Pollution from Solid Fuels in Developing Countries: Knowledge, Gaps, and Data Needs. Environ. Health Perspect. 2002, 110, 1057-1068. [CrossRef] [PubMed]

69. World Health Organization (WHO). Health as the Pulse of the New Urban Agenda: United Nations Conference on Housing and Sustainable Urban Development; WHO: Quito, Ecuador, 2016.

70. Dodge Data and Analytics. The Drive Towards Healthier Buildings 2016. Available online: https://www. worldgbc.org/sites/default/files/Drive\%20Toward\%20Healthier\%20Buildings\%202016_ffff.pdf (accessed on 2 October 2018).

(C) 2018 by the authors. Licensee MDPI, Basel, Switzerland. This article is an open access article distributed under the terms and conditions of the Creative Commons Attribution (CC BY) license (http://creativecommons.org/licenses/by/4.0/). 